\title{
АКАДЕМСКЕ БИБЛИОТЕКЕ У XXI ВЕКУ
}

\section{Сажетак}

Академске библиотеке почетком XXI века пролазе кроз значајне промене. У раду се разматрају питања у вези с технолошким променама, дигитализацијом, начинима коришћења библиотечко-информационог материјала. Као пример разматра се процес осавремењавања рада Централне библиотеке Универзитета у Новом Саду. Ова библиотека основана је 2003. године и до данас је прерасла из минијатурне ректоратске библиотеке у универзитетску библиотеку са респектабилном опремом и савременим начином пословања.

Кључне речи: Академске библиотеке, Централна библиотека Универзитета у Новом Саду

У раду који је презентован на Данима библиотека и библиотекара у Новом Саду априла 2018. године, поставила сам неколико питања која се тичу библиотека и библиотекарства: 1) Да ли се већ сада на почетку века могу назрети правци у којима ће се развијати библиотекарство и како ће изгледати библиотеке у будућности? 2) Шта се очекује од библиотекара у дигиталном свету? Разматрала сам све ова теоријска питања без посебног осврта на академске библиотеке и на циљеве и задатке које те библиотеке имају у свом окружењу.

Зна се да се у савременом свету сви типови библиотека боре са проблемима у вези с простором. Тај проблем настаје због промена у систему учења, у односу према знању и књигама, али и према библи-

Централна библиотека Универзитета у Новом Саду, Др Зорана Ђинђића б.б, 21000 Нови Сад mirjana.brkovic@uns.ac.rs 
отекама. Класичне универзитетске библиотеке познавале су три типа просторија: 1) канцеларија библиотекара, 2) читаонички простор и 3) магацински простор. Фотокопирнице су понекад биле у саставу библиотеке, а понекад одвојене од ње. Будући да је издавачка делатност универзитета понекад била у саставу академске библиотеке, и о тим просторијама се морало водити рачуна. У савременом свету, библиотекама су потребни простори који имају нове намене, раније непознате. Стога бисмо овај списак могли наставити на следећи начин: 4) интернет учионица, 5) просторија за дигитализацију, 6) просторије за индивидуално учење, 7) просторије за релаксацију корисника, поред оних који јављају у савременом библиотекарству, генреално гледано: уметнички атељеи, филмске сале, сале за преснимавање музике, галеријски простор и просторије за читање поезије.

Централна библиотека Универзитета у Новом Саду настала је као део Ректората 2003. године. Тада није постојао посебан простор за библиотеку, односно, решење је било провизорно у оквиру 3. и 4. спрата куле на адреси Трг Доситеја Обрадовића 5. Није постојала ниједна адекватна библиотечка просторија: 1) радни простор библиотекара био је смештен у Канцеларију за дактилографа; 2) читаонички простор био је смештен у Свечану салу, тако да се могао користити само након 15 часова када би се завршиле седнице и друге активности у Свечаној Сали, а 3) магацински простор није постојао, већ су публикације биле смештене у Свечаној сали и у кабинетима ректора и проректора. То је, дакако, значајно сметало се да нормално обављају библиотечки послови.

Сеобом у нове просторије 2008. године, тј. у приземље Студентског дома „Слободан Бајић” на адреси Др Илије Ђуричића 3, дошло је до видног побољшања ситуације везане за простор. Добијене су две подједнаке просторије у којој су биле смештене 1) канцеларија библиотекара и 2) читаоница, док су као 3) магацин служиле обе просторије, али и ректорски и проректорски кабинети на адреси Трг Доситеја Обрадовића 5, да би на крају део књига био смештен и у полице у ходнику Централне библиотеке.

Када се Централна библиотека 2013. године уселила у Централну зграду Ректората на адреси Др Зорана Ђинђића 1, добијене су три просторије - 1) канцеларија библиотекара, 2) читаоница и 3) мага- 
цински простор. То је био велик напредак у односу на претходно стање, међутим, уз добра решења, морала су бити прихваћена и она мање добра, као, на пример, да је канцеларија библиотекара истовремено и просторија за дигитализацију.

1) У канцеларију библиотекара смештене су све машине које су набављене за превентивну заштиту књига. Неке од тих машина праве буку, али се не користе свакодневно, тако да нису стална сметња при раду. Међутим, у исту просторију је смештен и роботизовани скенер који је веома бучан. Било је ситуација у којима се у радном простору библиотекара истовремено одвијала обука за дигитализацију, сама дигитализација и сви процеси који су природни за академску библиотеку. Овај проблем би се могао решити отварањем специјалног простора за дигитализацију, али то до сад није учињено.

2) Ормани који су постојали у Читаоници Централне библиотеке били су наменски прављени за књиге, али приликом сеобе остављени су у старом простору. Уместо њих су набављени бели, високог сјаја, елегантни, али са пуним вратима и без кључа. Другим речима, то су ормани који су погодни за канцеларије, али не и за библиотеке, тако да енциклопедије, речници и приручници који би могли бити смештени у Читаоницу, никада нису у њу унети. То се надоместило могућношћу коришћења интернета који је бесплатан за све кориснике читаонице, али недостатак књига на зидовима чини читаонички простор хладним и стерилним. Ова одлука је донета зато што се Универзитет у Новом Саду уговором обавезао да неће уносити другачије ормане у своје просторије, најмање две године након усељења у Централну зграду, да не би била нарушена естетска идеја архитекте.

3) Надаље, што се магацинског простора тиче, постоје и добре и лоше стране. Добра је што је магацин у просторији која је укопана у земљу и без прозора, тако да су и температура и влажност ваздуха константни. У новом магацину нема штетног осунчавања публикација какво су публикације трпеле у претходном простору, будући да на прозорима нису годину дана постојали застори, па чак ни завесе, које би спречиле осунчавање. Ово су добре стране новог магацина, а негативно је што ни та просторија није грађена наменски за смештај библиотечког материјала, тако да су на плафону магацина изукрштане водоводне и канализационе цеви без посебне изолације. Књиге 
су до сада два пута претрпеле поплављивање на адреси Др Илије Ђуричића 3 , а у новом магацину још једно. Неке од публикација су се оштетиле, тако да ћемо морати да их надоместимо када будемо имали довољно материјалних средстава за то.

Планирање библиотечког простора је, као што се види, један од важних фактора када говоримо о савременим библиотекама. Кључна питања о којима би требало размишљати у вези са библиотечким простором, ${ }^{1}$ без обзира на то колика је садашња библиотека, сматрају стручњаци су следећа:

1. Радите ускладу са простором којим располажете, а не упркос њему. - Централна библиотека Универзитета у Новом Саду смештена је у простор који је успела да добије у Централној згради Универзитета, од којих је првобитно само простор за Читаоницу био намењен Централној библиотеци, стога смо се потрудили да се уклопимо у постојеће ресурсе.

2. Максимално искористите природно осветљење. - Што се тиче природног осветљења, њега има довољно, јер је читава Централна зграда рађена у стаклу и архитектонски је решено да буде потпуно транспарентна. Повремено се брисолеје, аутоматски застори, сами затворе и настане полумрак у Читаоници и у канцеларији библиотекара. Уколико се то деси ван радног времена библиотекара, застори остану затворени све до наредног дана.

3. Створите утисак код корисника да су стигли на право место. - Централна библиотека се потрудила да уреди просторију украсним, собним биљкама, али будући да је читава просторија у црним и белим тоновима, делује хладно и празно. Идеје постоје, да се набаве на пример, јастучићи за столице у разним бојама, али све то није блиско управи, већ остаје увек на нивоу идеје.

4. Учините скровита места транспарентним. - Скровита места у Читаоници не постоје, као ни баријере, све је заиста изложено свачијем погледу, једино што није транспарентно јесте

1 Opening the Book Ltd, Library Space Planning (http://www.openingthebook. com/library-space-planning 23. 5. 2018) 
магацин с књигама који је у затвореном приступу. „Прозор” у магацин чине каталошки записи о књигама за које се сви у библиотеци труде да буду што тачнији и потпуно ажурни.

5. Начините мали излог, свако се заустави код производа који му излази у сусрет. - Идеја да треба да се начини мали излог, јер свако се заустави код производа који му излази у сусрет, у Централној библиотеци није уродила плодом. Наиме, више пута смо стављали рекламни материјал на видна места у читаоници, очекујући да ће корисници узети тај материјал, али то се није десило. На крају смо материјал покупили и склонили, јер је постао недовољно актуелан.

6. Пружите корисницима више могућности да би сами бирали где ће да седну или да уче. - У случају Централне библиотеке Универзитета у Новом Саду не може се изаћи корисницима у сусрет и омогућити им да седну да уче где им је воља, јер постоји само Читаоница у којој могу да раде. Нигде више у Централној згради није им дозвољено дуже задржавање, до те мере да се повремено закључава и кантина у којој желе да поједу сендвич или напросто да попричају са пријатељима.

7. Сведите баријере и контролне пунктове на минимум. - Контролни пунктови се постављају у складу са налогом ректора, а он их поставља у складу са општим захтевима за безбедност на радном месту. Тако се приликом уласка у Централну зграду свако јавља прво портиру, а потом и дежурној која уписује име и презиме посетиоца. У случају да су посетиоци - корисници Читаонице, они се својеручно потписују и дају назив факултета на којем студирају и број индекса, како би постојала евиденција о боравку одређене особе у Централној згради. (Имали смо два случаја крађе, једном је украден новчаник, а други пут су нестала документа, па су надлежни посумњали у назови читаоце, тј. неколико особа које су се лажно представљале као да су студенти). Након уласка у Читаоницу, слободни су да је користе без икаквих ограничења, али у складу са нормалним и уобичајеним понашањем. 
8. Користите боје и слике како бисте створили пријатан амбијент и стимулисали учење. - У свету је природно да се користе боје и слике како би се створила пријатна атмосфера, леп амбијент и стимулисало учење, али у случају Централне библиотеке тако нешто није неопходно, јер су два зида у готово потпуно у стаклу, тако да се природа побрине да створи леп амбијент и пријатно окружење. Боје се смењују - од јарко зелене у пролеће и лето, преко топлих црвених и смеђих у јесен, до прелепе беле у зимском периоду. Тиме је додатно украшавање просторије постало помало излишно.

9. Користите сводове како бисте отворили нове просторе. Слично је и са сводовима у Централној библиотеци у новој згради, јер је непотребно ширити просторију која сама по себи има преко 100 квадратних метара. У претходној канцеларији, заиста су били порушени преградни зидови између две просторије и уграђени сводови, тако да смо имали један нов, већи и пријатнији радни простор.

10. Избегавајте традиционалне низове столова и полица који креирају осећај да смо у фабрици или складишту, а не у библиотеци. - Што се тиче традиционалног низања столова и полица, занимљиво је истаћи да се студенти труде да унапред уређен простор у Читаоници не преуређују. Померања столова су минимална и своде се, углавном, на приближавање стола утичници, како би се допунила батерија на лаптопу. Иако су прошле већ више од четири године од усељења у Централну зграду, студенти не показују жељу да окрену сто један према другом или да направе некакав комплет столова где би седели у групи од по четворо или више студената. Свако седи сам за столом, а када желе да комуницирају међусобно, изађу из Читаонице. С друге стране, већ је речено да у овом моменту немамо никакве полице у читаоници које би могле да створе осећај да смо у складишту, али у библиотеци је, ипак, логично да постоје неки приручници доступни читаоцима. Док се не дигитализују енциклопедије, студенти су приморани да користе електронске изворе са интернета или да се обрате дежурном библиотекару за 
помоћ. Стога студенти, углавном, доносе своју литературу из које читају и уче, а библиотечки фонд остаје скривен од њихових очију.

Већина библиотека у XXИ веку остаће без фондова који ће се смештати у магацине, нарочито зато што је све већа потражња за слободним местом у читаоницама, па се поставља питање како преуредити библиотеку након дигитализације. Међутим, Централна библиотека је већ уређена на тај начин да су читаоци и публикације на два различита места, тако да преуређења неће ни бити. Када се прешло на дигиталне каталоге и на ОРАС, то је значило престанак умножавања папирних каталошких листића. Ни у вези с тим Централна библиотека Универзитета у Новом Саду није имала никакав проблем, јер није ни било претходне фазе када су се листићи израђивали.

У Закону о дигитализацији библиотечке грађе се не говори о расходовању фонда који је дигитализован, али судећи по искуствима иностраних библиотека, то и није циљ. Чувају се, најчешће, оба формата - и папирни и електронски. За чување електронског формата неопходно је водити рачуна о његовој употребљивости током времена, јер ће електронски носачи типа CD-rom и DVD-rom бити ограниченог рока трајања који је нешто више од 25 година. Након разговора са стручњацима из Центра за информационе технологије Универзитета у Новом Саду, дошли смо до закључка да би најједноставније било да се превелики фајлови који настају дигитализацијом пресниме на DVD-rom електронске носаче који би се адекватно означили и самим тим били претраживи. Након тога би се отворио проблем чувања дотичних DVD-а и њиховог смештаја и заштите, али у овом моменту сви DVD-и су у канцеларији библиотекара.

Библиотекари су и даље кључни фактори у развоју библиотека и библиотекарства, без обзира на то да ли их називају информаторима, менаџерима информација, дигитализаторима и слично. Постоје стереотипи о библиотекарима, као што је познато. У библиотеци би према том стереотипу требало да ради библиотекарка која је старија женска особа, носи наочаре с великом диоптријом, коса јој је повезана у чврсту пунђу и увек је спремна да утиша присутне једним „Шшшш“. Међутим, данашњи библиотекари у већини случајева не 
изгледају тако, а ово су само неке од фотографија библиотекара који су радили у Централној библиотеци Универзитета у Новом Саду од њеног оснивања 2003. до данас.
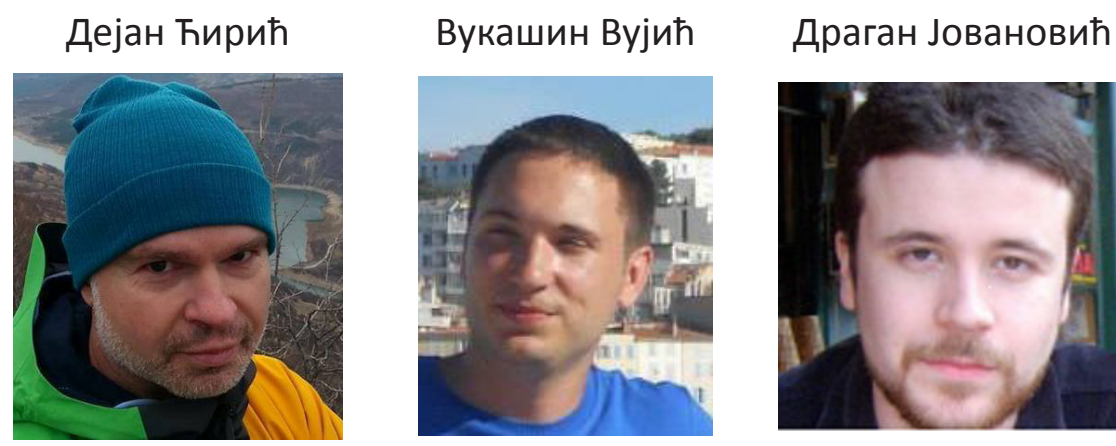

Стефан Савић

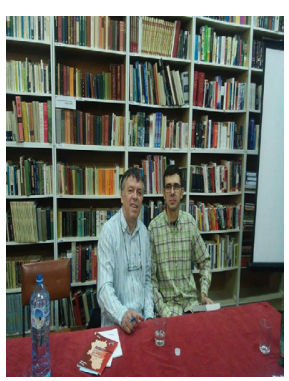

Филип Маринковић

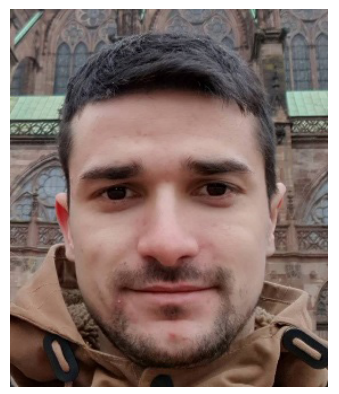

Олга Кхамилова

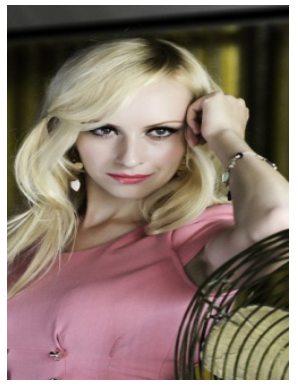

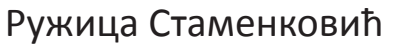

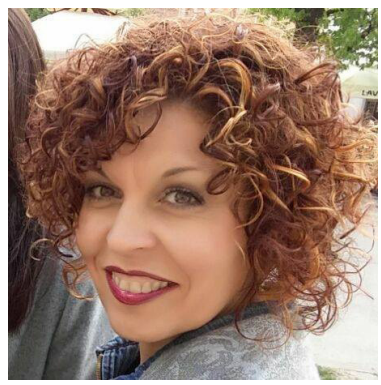

Ивана Иконић

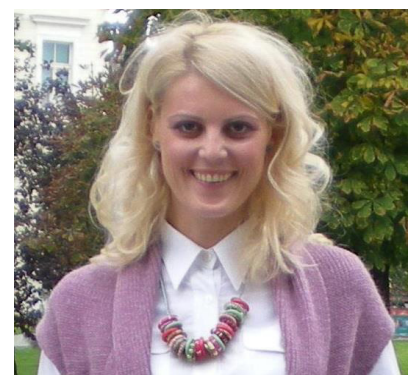


Бранка Лазић

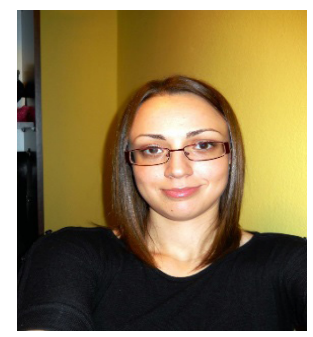

Оливера Обрадовић

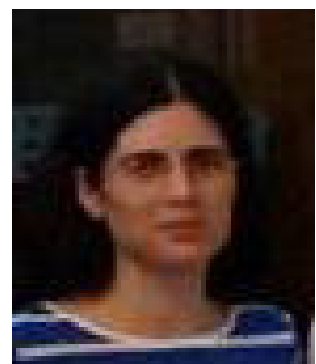

Весна Поповић

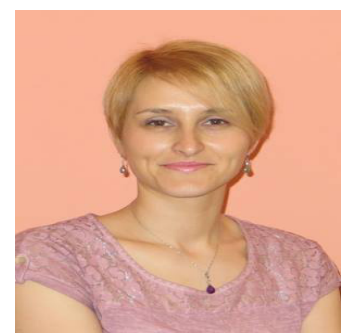

Драгана Симеуновић

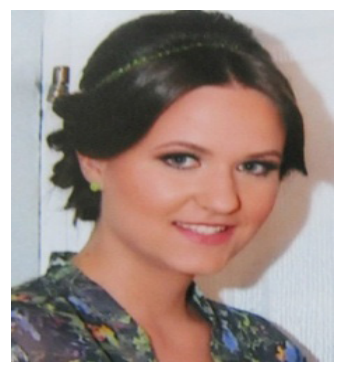

Али није реч само о стереотипу и само о визуелном утиску који остављају библиотекари на своје кориснике. Реч је о суштинским променама које су захватиле нашу професију и које се могу груписати на следећи начин. Библиотекари морају да буду:

- образовани, јер би требало да дају одговоре на различита питања,

- да разумеју нове услове и начине учења,

- да адекватно одговарају на нове потребе које имају њихови корисници,

- да буду прилагодљиви и

- да буду комуникативни како би што лакше обављали своје послове.

Што се тиче образовања кадрова у Централној библиотеци Универзитета у Новом Саду, може се говорити само о образовању управника Централне библиотеке, јер се од фебруара 2003. до маја 2018. године, тачније за деценију и по, ниједан нов библиотекар 
није запослио у њој на дуже од годину дана. У међувремену, као управник, обучила сам 10 практиканата да могу да раде самостално у библиотекама (једино је Ружица Стаменковић дошла у Централну библиотеку да волонтира као библиотекар с положеним стручним испитом). Сваки практикант је имао претходно завршене основне или мастер студије. За обављање стручне праксе највише се јавило професора српске књижевности и језика (или обрнуто), економиста, професора француског језика и књижевности, биолог и само један дипломирани библиотекар и информатичар.

Сваки практикант који је обављао стручну праксу у Централној библиотеци био је обавезан да бар једном током године присуствује неком од предавања или семинара које су организовале Централна библиотека Универзитета у Новом Саду, Библиотека Матице српске, Градска библиотека у Новом Саду, Народна библиотека Србије или Универзитетска библиотека „Светозар Марковић“ у Београду. Као млади људи који су, углавном, непосредно пре тога дипломирали или положили мастер испит, с лакоћом су разумевали нове начине учења (углавном електронске) и могли су адекватно да одговоре на нове потребе корисника. Те нове потребе смо препознавали у слању електронских верзија доктората, а касније и изради дигиталних копија монографских публикација на појединачан захтев, претраживање електронских база преко КоБСОН-а за особе које нису запослене у академским институцијама, а студирају на Универзитету у Новом Саду и сл. Свако од практиканата је прихватао све услове рада у Централној библиотеци, чак и када су то били захтеви да се ради прековремено или викендом или када су биле по среди сеобе или тријажирање књига, па је то подразумевало физички рад, рад у нехигијенским условима и сл. Сваког практиканта сам од првог до последњег дана рада покушавала да обучим за рад у пословном окружењу, што је значило да сам им говорила о: кодексу облачења у јавним институцијама, кодексу понашања на радном месту, начинима обраћања и комуникације телефоном, начину писања и именовања пословних мејлова, изради извештаја и других аката, коришћењу меморандума и печата, што све није уско повезано само са библиотечким пословима, али јесте део пословања сваке институције, па и библиотеке. 
А ево шта се каже какви ће бити библиотекари сутрашњице: самоуверени, желе да уче, желе да пруже помоћ другима, одлучни су, самопрегорни, спремни су да прихвате изазове и умеју да раде унутар параметара свог посла. Као библиотекар с 33 године радног стажа у библиотекарству, прошла сам све нивое рада у библиотекама - од рада у малој школској библиотеци где су ми корисници имали између 7 и 15 година; преко послова манипуланта у Одељењу за старе и ретке књиге и легате и послова информатора у Одељењу за коришћење публикација у Библиотеци Матице српске, где су ми корисници били од 18 до 80 и више година старости; до послова у Централној библиотеци на месту управника где су људи са којима контактирам свих узраста и свих образовних нивоа и социјалних статуса. Оно што сам научила је да је љубазан и пријатан начин опхођења важан како при сусрету с дететом које можда први пут у животу види библиотекара, тако и при комуникацији с професорима, ректорима, академицима, амбасадорима или министрима, који су се небројено пута сусретали с нашом професијом. Драго ми је кад сам у прилици да своје животно искуство поделим с другима и понудим нека од решења која сам сама испробала. Време ће показати да ли је практичан рад који су млади људи обављали у Централној библиотеци Универзитета у Новом Саду био за њих користан и да ли ће им помоћи да одговоре на захтеве сутрашњице. 
Mirjana Brković, PhD

University of Novi Sad

Central Library

\section{ACADEMIC LIBRARIES IN XXI CENTURY}

\section{Summary}

At the beginning of the XXI Century academic libraries are going through important changes. In the paper are discussed issues of technological changes, digitalisation, the usage of library-information material. The process of innovating of the University of Novi Бад Central Library is used in this case study. The Library is established in 2003, but until today it has undergone the improvement from miniature library of Rectorate, to the University Library with respectable equipment and up-to-date workflow.

Key words: Academic libraries, University of Novi Sad Central Library 